Efficient Vol 1 (2) (2018): 167-178 DOI: https://doi.org/10.15294/efficient.vii2.30152
$\begin{gathered}\text { Indonesian Journal of Development Economics } \\ \text { https://journal.unnes.ac.id/sju/index.php/efficient }\end{gathered}$
ise

\title{
Effectivity and Efficiency of Regional Property Management Results and Financial Performance
}

\author{
Tasyaa'u Mulka Thafaki \\ Jurusan Ekonomi Pembangunan, Fakultas Ekonomi, Universitas Negeri Semarang \\ Permalink/DOI: https://doi.org/10.15294/efficient.vii2.30152
}

Received: January 2018 ; Accepted: March 2018 ; Published: Juny 2018

\begin{abstract}
The purpose of this research to determine the level of efficiency and results that reflect the performance and financial performance of BUMD in Semarang City, period 2014-2016. The type of data used is secondary data, using data analysis through DEA analysis and interview method. The results showed that PDAMs and RPH \& BPH in 2014 still met the level, with a value of $82.4 \%$ and $62.6 \%$. In 2015, as a whole, BUMD has achieved the value of efficiency and effectiveness. In 2016 $R P H$ \& BPH companies have not been able to reach the level of $8.1 \%$. The level of appeal in the 2014 and 2015 BPR BKK will jointly achieve a joint achievement level of $89.5 \%$ and $93.8 \%$. Using a comprehensive annual calculation of BUMD has reached the level of effectiveness with a value of $100 \%$.
\end{abstract}

Keywords: Effectivity, Efficiency, Results of Regional Property Management, Financial Performance.

\begin{abstract}
Abstrak
Tujuan penelitian ini untuk mengetahui tingkat efisiensi dan hasil yang mencerminkan kinerja dan kinerja keuangan BUMD di Kota Semarang, periode 20142016. Jenis data yang digunakan adalah data sekunder, menggunakan analisis data melalui analisis DEA dan metode wawancara. Hasil penelitian menunjukkan bahwa PDAM dan RPH \& BPH pada tahun 2014 masih memenuhi level, dengan nilai 82,4\% dan 62,6\%. Pada 2015, secara keseluruhan, BUMD telah mencapai nilai efisiensi dan efektifitas. Pada 2016, perusahaan RPH \& BPH belum dapat mencapai level 8,1\%. Tingkat banding di BPR BKK 2014 dan 2015 akan bersama-sama mencapai tingkat pencapaian bersama sebesar 89,5\% dan 93,8\%. Menggunakan perhitungan tahunan BUMD yang komprehensif telah mencapai tingkat efektifitas dengan nilai $100 \%$.
\end{abstract}

Kata Kunci: Efektivitas, Efisiensi, Hasil Pengelolaan Properti Daerah, Kinerja Keuangan.

How to Cite: Thafaki, T. (2018). Effectivity and Efficiency of Regional Property Management Results aI Performance. EFFICIENT Indonesian Journal of Development Economics, 1(2), 167-178. https://doi.org/10.15294/efficient.vii2.30152,

(C) 2019 Semarang State University. All rights reserved

\footnotetext{
Alamat Korespondensi :

Alamat: Gedung L2 Lantai 2 FE Unnes

Kampus Sekaran, Gunungpati, Semarang, 50229

E-mail : efficientjournal@gmail.com
}

ISSN 


\section{INTRODUCTION}

Along with the enactment of regional autonomy on January 1, 2001, the regional government aggressively carried out the development and improvement of regional quality in all fields. With the issuance of regional autonomy according to UU No 32 of 2004 about Regional Government and UU No 33 of 2004, about the financial balance between the regions and the center, giving consequences to the regions concerned to carry out pensions in some aspects requires the regional government to take care of all regional needs. independently one of them is Regional Finance: before and after Autonomy Regional authority in running its government during the New Order period is based on the
Law. No. 5/1974. Besides regulating regional government, the Act also explains the financial relationship between the central government and local government (Suseno, 2013) which is included in the Regional Original Revenue.

Regional Original Revenue is divided into four regional income results namely. Income from tax revenue, income from acquisition of levies, results of management of separated assets, and other income. Position of income from the management of separated regional assets is obtained after tax revenue and retribution on PAD Semarang City. Following are the Semarang City PAD reports for 2014-2016.

Table 1. Realization of Regional Original Revenue (PAD) in Semarang City period 2014-2016

\begin{tabular}{|c|c|c|c|}
\hline PAD & Realization 2014 (Rp) & Realization2015 (Rp) & Realization $2016(\mathrm{Rp})$ \\
\hline Tax & 791.509 .586 .089 & 816.208 .853 .784 & 1.006 .487 .472 .776 \\
\hline Retribution & 110.491 .080 .293 & 88.329 .210 .805 & 123.215 .026 .523 \\
\hline $\begin{array}{l}\text { Results of Regional } \\
\text { Property Management }\end{array}$ & 8.036 .099 .560 & 10.530 .576 .700 & 13.408 .979 .748 \\
\hline $\begin{array}{l}\text { Other } \\
\text { Income }\end{array}$ & 228.330 .462 .551 & 286.513 .137 .170 & 348.534 .421 .018 \\
\hline Total & 1.138 .367 .228 .493 & 1.201 .581 .778 .459 & 1.491 .645 .900 .065 \\
\hline
\end{tabular}

Sources : Tren Realization Income dan Expenditure Semarang City 2010 - 2016

In the PAD Realization table explains that Regional Tax Revenue has the highest position, where the realization in 2016 there was an increase in value. In the table above, it is explained that the overall income, namely income from taxes, retributions, profits from BUMD profits and other legitimate income, has increased, but for the Income of Regional Wealth Management Results which are separated from profits BUMD only contribute ten percent to Original Income Area.
Semarang has six companies engaged in agriculture, livestock, printing and credit. Each regional company has the ability to suit their fields to deposit profits after the regional development funds. The income from the management of separate regional assets together with the names of registered regional companies can be seen in table 2 attached.

Based on the table data above the data used is Rp51,979,633,000.00 realized amounting to Rp19,031,355,630.oo or $36.61 \%$. 
Compared to the realization of the 2015 fiscal year of Rp. 13,408,979,748.00, the progress of the increase was Rp. 5,622,375,882.00. This increase is in accordance with the profits obtained by the Bank of Central Java, Perusda RPH and BPH, Perusda Percetakan, Perusda Bank Pasar, Perusda regional BPR / BKK, while those not realized are PDAM Tirta Moedal.
Some indicators are used to measure the total amount of assets and liabilities, profits derived from development funds, operating and operational income. In accordance with Regional Government Regulation Number 10 of 2014, there are three companies seeking assistance, namely PDAM Tirta Moedal, BPR BKK Semarang City, and Perusda RPH BPH.

Tabel 3. Financial Progress of BUMD in Semarang City Period 2014-2016

\begin{tabular}{llll}
\hline \multicolumn{1}{c}{ BUMD } & \multicolumn{3}{c}{ Year } \\
& \multicolumn{1}{c}{$2014(\mathrm{Rp})$} & \multicolumn{1}{c}{$2015(\mathrm{Rp})$} & \multicolumn{1}{c}{$2016(\mathrm{Rp})$} \\
\hline $\begin{array}{l}\text { Perusda RPH \& PBH } \\
\text { Total Assets }\end{array}$ & 7.504 .158 .500 & 7.615 .733 .053 & 7.489 .380 .475 \\
Equity & 7.475 .375 .854 & 7.615 .650 .849 & 7.487 .777 .205 \\
Profit (Loss) after Tax & $(67.707 .378)$ & 141.133 .327 & 10.871 .836 \\
PDAM & & & \\
Total Assets & 355.489 .304 .182 & 381.712 .980 .350 & 387.813 .449 .330 \\
Equity & $(137.584 .621 .183)$ & $(115.569 .766 .478)$ & 344.988 .463 .446 \\
Profit (Loss) after Tax & 4.224 .614 .916 & 5.958 .948 .244 & 17.196 .736 .745 \\
BPR BKK & & & \\
Total Assets & 130.599 .952 .564 & 153.158 .603 .572 & 167.112 .344 .955 \\
Equity & 25.849 .879 .464 & 28.671 .198 .928 & 31.031 .220 .099 \\
Profit (Loss) after Tax & 4.185 .272 .502 & 4.127 .684 .740 & 4.280 .892 .116 \\
\hline Sours : Econo
\end{tabular}

Sources : Economy Department of Setda in Semarang City

The table above explains the financial performance from three regional companies, namely PDAM, BPR BKK, and Perusda RPH \& BPH. The PDAM company has the greatest total assets among BPRs and RPHs because the PDAM has an important role in producing water throughout the City of Semarang. Meanwhile for BKK BPR there is an increase in demand for credit by the public. In the RPH \& BPH regulations due to the lack of income for slaughterhouses the company's total assets decreased. This condition is one of the burdens for the Government, because the realized income tends to decrease from the budget set by the government. So what is the objective of the establishment of BUMD is as a source of local government revenue has not been achieved.

\section{RESEARCH METHODS}

This study discusses the financial performance of BUMD which causes the nonrealization of revenue from the Wealth Management Results that are separated which are determined by the Semarang City Government. The analytical method used is a quantitative method with a percentage descriptive approach.

As for descriptive understanding According to Wahyudin (2015) is a method 
that serves to describe or give an overview of the object under study through data that has been collected as it is. Descriptive research is used to determine how deep the influence of the financial performance of regional companies in contributing profits to be included in the income from the results of wealth management separated in the city of Semarang.

This study uses Primary data and secondary data. Where primary data is data obtained directly in the field from the respondent or resource person such as interviews. Furthermore, the data will be processed by the author. In this study the data that the author uses as primary data is an interview to the resource persons in the financial sector of the company. Whereas Secondary Data is data obtained from Regional Companies in the form of Financial Reports (Balance Sheet and Profit and Loss Reports) and data on the development of the BUMD of Semarang City.

Data other than financial statements, namely data on the records of the Semarang City financial statements (CALK) that have been presented or published that are needed by the researcher, which relate to the research under study is documentation consisting of tables, and archives. The population of this study includes 6 BUMD companies. The following is data about BUMD / regional companies in the city of Semarang.

The sampling technique in this study was purposive sampling. Purposive sampling is intended because the researcher has a purpose to find out the cause of the discrepancy between the financial performance of the company and the addition of realized revenue from the management of the separated regional assets which has been determined by the Semarang City government.

Tabel 4. Regional Companies Or BUMD di Semarang City

\begin{tabular}{ll}
\hline No & Regional Companies / BUMD \\
\hline $\mathbf{1}$ & PDAM Tirta Moedal Kota Semarang \\
$\mathbf{2}$ & Perusda Percetakan \\
3 & Perusda RPH dan BHP \\
4 & PD. Bank BPR BKK \\
5 & PD. Bank Pasar \\
6 & Bank Jateng Cab. Kota Semarang
\end{tabular}

Sources: PPID Kota Semarang

The number of samples taken in this study are three regional companies from six regional companies namely PDAM Tirta Moedal, BPR BKK, and RPH \& BPH. This study uses a research informant or key person. As for the key person in this study is the Head of the finance department of PDAM Tirta Moedal and the Secretariat of Perusda RPH \& BPH The variables in this study use input variables and output variables to measure the effectiveness of financial performance and the results of separated wealth management. Input variables and output variables used in this study can be seen in table 5 .

Analysis data will be processed using DEA (Data Envelopment Analysis) analysis tool first introduced in 1978 by Charnes A, Cooper WW and Rhodes E in the Operational Research journal entitled "Measuring The Efficiency of Decision Making Units". The journal discusses the development of efficiency decision making steps that can be used in evaluating the Decision Making Unit (Charnes et al., 1978, in Israwan (2016) 
Tabel 5. Variabel input and output

\begin{tabular}{|c|c|c|c|}
\hline $\begin{array}{l}\text { Variabel } \\
\text { Input }\end{array}$ & Information & Variabel Output & Information \\
\hline $\begin{array}{l}\text { Government } \\
\text { Equity } \\
\text { Participation }\end{array}$ & $\begin{array}{l}\text { The total amount is the } \\
\text { authorized capital of the } \\
\text { company and the capital } \\
\text { deposited by the goverment of } \\
\text { Semarang City. }\end{array}$ & Tax After Profit & $\begin{array}{l}\text { The total amount of } \\
\text { the company's profit } \\
\text { that has been reduced } \\
\text { by the profit of BUMD } \\
\text { to the local } \\
\text { government. }\end{array}$ \\
\hline Total Asset & $\begin{array}{l}\text { The total amount of cash, } \\
\text { corporate receivables and } \\
\text { inventories. }\end{array}$ & $\begin{array}{l}\text { Results of } \\
\text { Management of } \\
\text { Wealth of Separated } \\
\text { Areas }\end{array}$ & $\begin{array}{l}\text { The amount deposited } \\
\text { by the BUMD for the } \\
\text { local government to } \\
\text { increase the PAD of } \\
\text { Semarang City }\end{array}$ \\
\hline Equity & $\begin{array}{l}\text { The amount of authorized } \\
\text { capital of the company is } \\
\text { reduced by current year profit. }\end{array}$ & & \\
\hline
\end{tabular}

Data Envelopment Analysis (DEA) method is made as a tool to evaluate the performance of an activity in an entity unit (organization). Basically the working principle of the DEA model is to compare input and output data from an organization (decision making unit, DMU) with other input and output data in the same DMU. This comparison is done to get an efficiency value. The basic measure used in the DEA is the ratio of the total total output input.

$$
\begin{aligned}
& \text { Efisiensi }=\frac{\text { Input }}{\text { Output }} \ldots . . \\
& \text { Efektivitas }=\frac{\text { output }}{\text { Input }} .
\end{aligned}
$$

The input accumulation process can be described as follows:

Virtual Input $=\sum_{I=1}^{I} u_{i} x_{i}$

With ui is the weight of the input xi during the accumulation process. For output can be described as follows:

Virtual Output $=\sum_{j=1}^{j} V_{j} Y j$

If there is an $\mathrm{N}$ DMU that will be compared to the level of effectiveness, then the linear fractional form of the DEA program is as follows:

$\max E m=\frac{\sum_{j=1}^{j} V j m Y j m}{\sum_{I=1}^{I} \mathcal{U}_{i} \chi_{i}}$

Subject to 
$0 \leq \frac{\sum_{j=1}^{j} V j m Y j m}{\sum_{I=1}^{I} \mathcal{U} i \mathcal{X}_{i}} \leq 1 ; n=1,2, \ldots, N \ldots \ldots(6)$

$V_{j m} U_{j m} \geq 0 ; i=1,2, \ldots I ; j=1,2, \ldots, J$

Information :

Em is a efektivity of Results of Management of Wealth of Separated Areas.

yjm is output companies.

vjm is bigger of output.

xim is input companies.

uim is bigger of input.

yjn dan xin is output companies dan input companies for all DMU ke- $n, n=1,2, \ldots, N$. And $m$ is the pieces of $n$.

The results of these calculations are presented in the form of bar charts. Next the researcher will interpret the diagram descriptively and be linked to the relevant theory to get a conclusion.

\section{RESEARCH RESULT}

Level of Efficiency and Effectiveness of Regionally Owned Enterprises (BUMD) in Semarang City Year 2014

Semarang City BUMD whose efficiency level has been efficiency in accordance with the variables (Total Assets, Equity, Profit After Tax, Dividends to Government, and Capital) in 2014. With the results of data management using the estimation analysis tool Banxia Frontier Analysis 3.0 shows that the BPR BKK Company has an efficiency value of 1 or $100 \%$.

Meanwhile, two BUMD companies namely Perusda RPH \& BPH and PDAM Tirta Moedal did not achieve an efficiency score of less than 1 or $<100 \%$. In Perusda $\mathrm{RPH} \& \mathrm{BPH}$ has an inefficiency value of 0.6258 or $62.6 \%$. The PDAM Tirta Moedal Company has an inefficiency value of 0.8243 or $82.4 \%$. Following are the results of efficiency management in 2014 .

Picture 1. Level of Efficiency and Inefficiency of the Semarang City BUMD period 2014

\section{BUMD Eficiency Value in 2014}

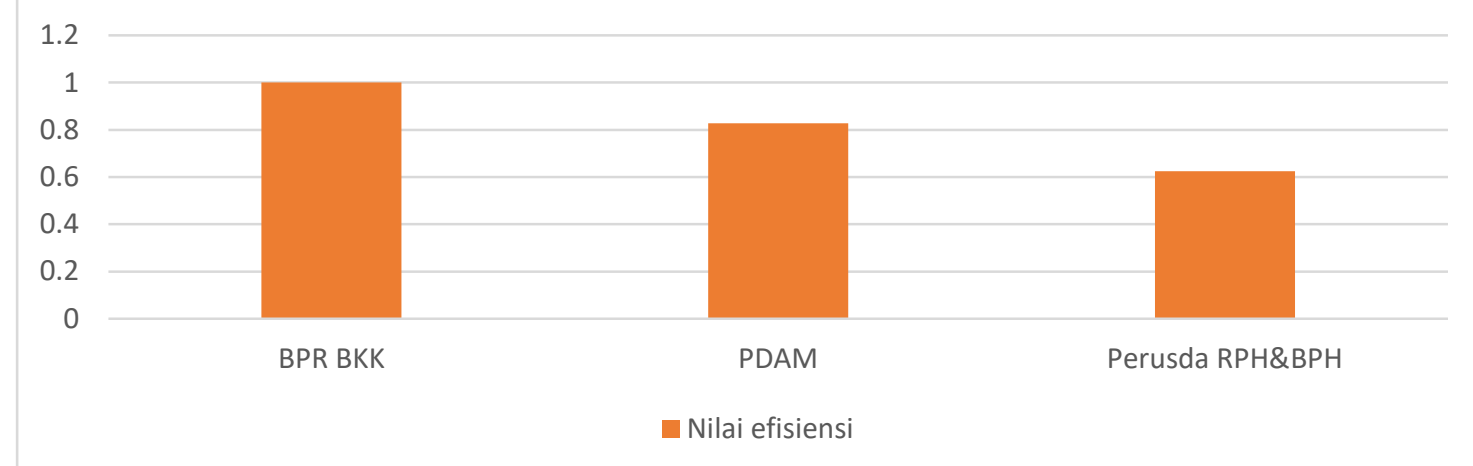

Sources: Data processed, 2018

For measurement of effectiveness in Semarang City BUMD in 2014 by using variables (earnings after tax and dividends to the government) with variables that do not affect the variable capital. With the results With the results of data management using an estimation analysis tool Banxia Frontier Analysis 3.0 shows that the 
three BUMD companies namely BPR BPH have an effectiveness value of 1 or $100 \%$. BKK, PDAM Tirta Moedal, and Perusda RPH \&

Picture 2. Level Efektivity BUMD in Semarang City Period 2014

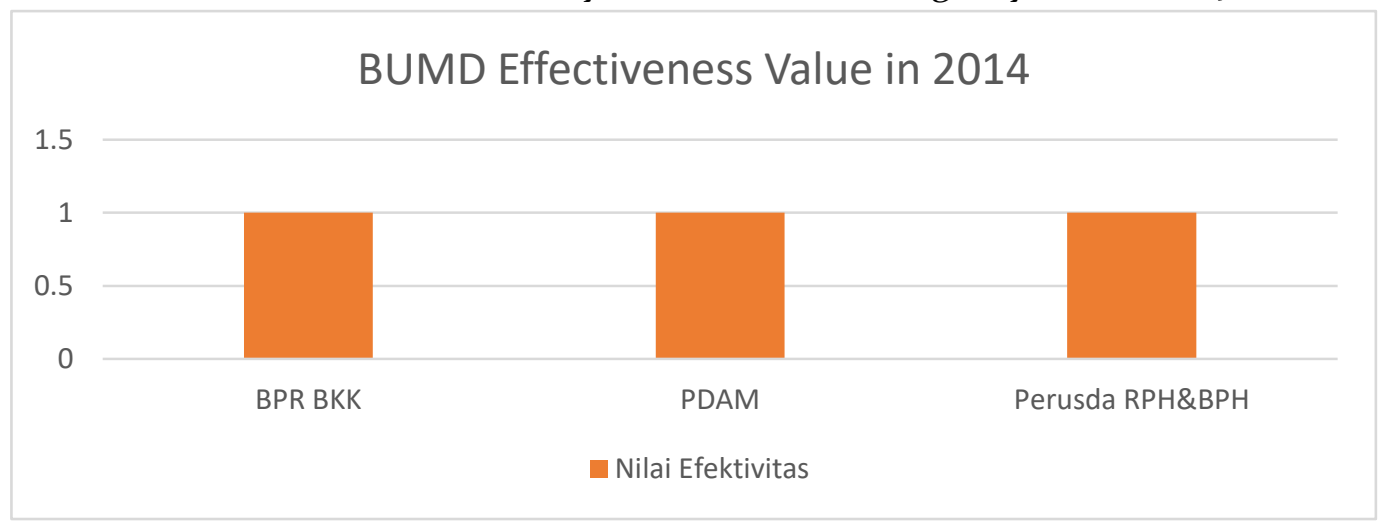

Sources: Data processed, 2018

Level of Efficiency and Effectiveness of Regionally Owned Enterprises (BUMD) in Semarang City Year 2015

Semarang City BUMD whose level of technical efficiency has been efficiency in accordance with variables (Total Assets, Equity, Profit After Tax, Dividends to Government, and Capital) in 2015.
With the results of data management using the estimation analysis tool Banxia Frontier Analysis 3.0 shows that the three BUMD Companies namely BPR BKK, PDAM Tirta Moedal, and Perusda RPH \& BPH have efficiency values of 1 or $100 \%$. Following are the results of efficiency management in 2015.

Picture 3. Level of Efficiency and Inefficiency of the Semarang City BUMD period 2015

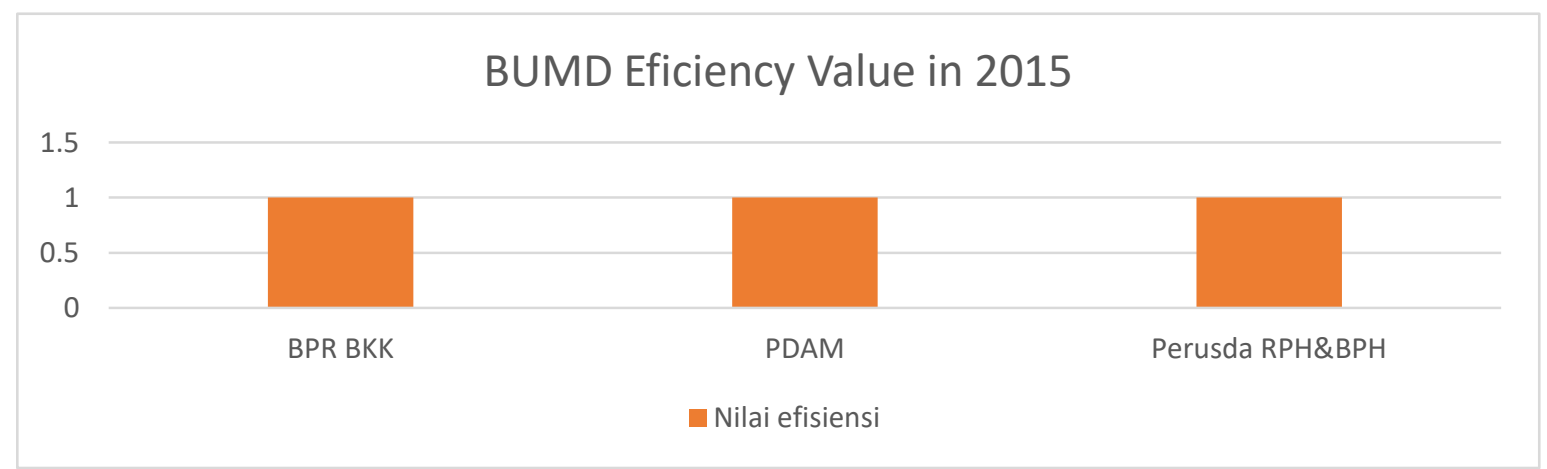

Sources: Data processed, 2018

For measurement of effectiveness in variables that do not affect the variable capital. Semarang City BUMD in 2015 by using the With the results With the results of data output variable namely profit after tax and management using an estimation analysis tool dividends to the government with additional Banxia Frontier Analysis 3.0 shows that the 
three BUMD companies namely BPR BPH have an effectiveness value of 1 or $100 \%$ BKK, PDAM Tirta Moedal, and Perusda RPH \&

Picture 4. Level Efektivity BUMD in Semarang City Period 2015

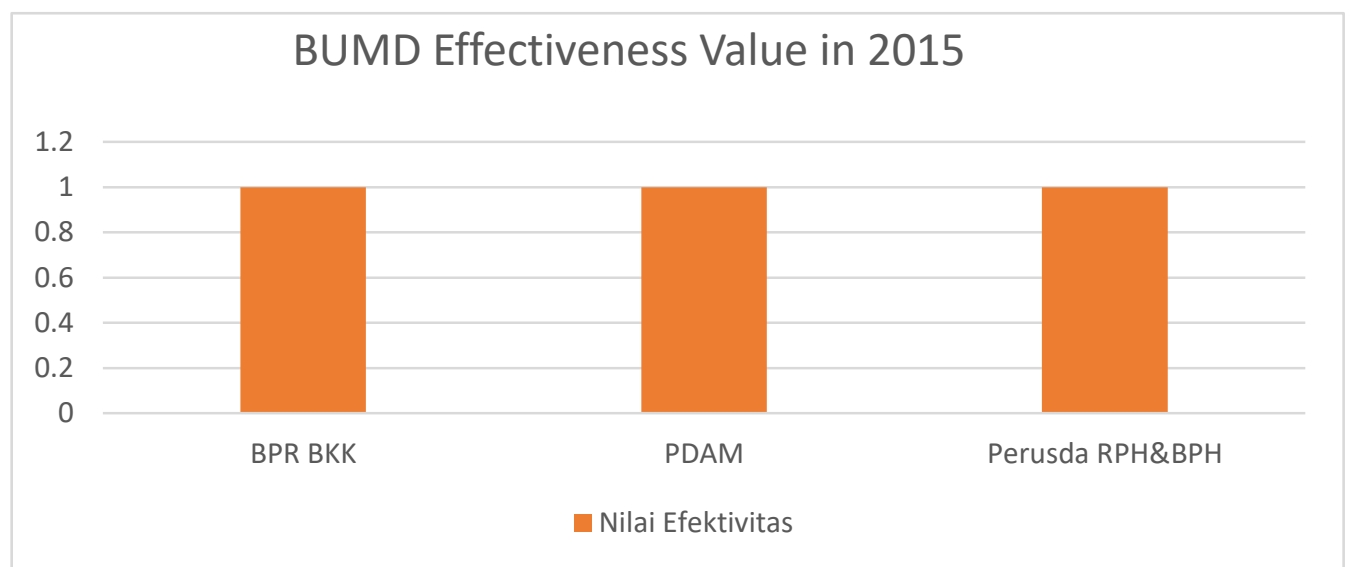

Sources: Data processed, 2018

Level of Efficiency and Effectiveness of Analysis 3.0 shows that two BUMD Companies Regionally Owned Enterprises (BUMD) in namely BPR BKK, and PDAM Tirta Semarang City Year 2016 Moedal, which have efficiency values of 1 or Semarang City BUMD whose level of 100\%. While BUMD companies namely technical efficiency has been efficiency in accordance with the variables (Total Assets, Equity, Profit After Tax, Dividends to Perusda RPH \& BPH do not achieve an efficiency value of less than 1 or $<100 \%$. In Perusda RPH \& BPH has an inefficiency Government, and Capital) in 2016. With the results of data management using the value of 0.808 or $8.1 \%$. Following are estimation analysis tool Banxia Frontier

Picture 5. Level of Efficiency and Inefficiency of the Semarang City BUMD period 2016

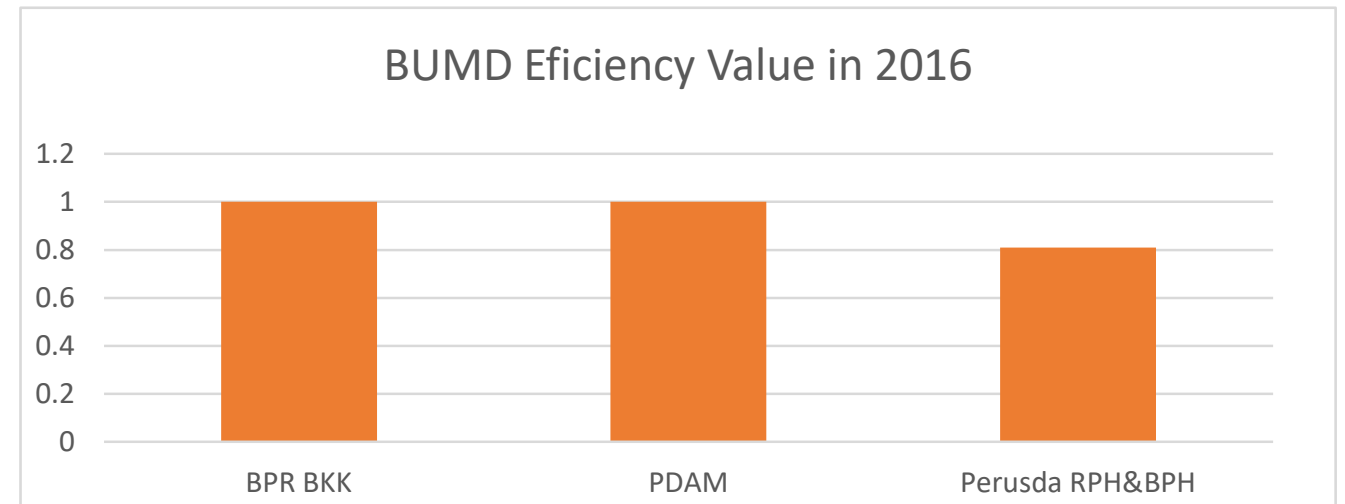

Sources: Data processed, 2018

For the measurement of effectiveness in Semarang City BUMD in 2016 by using the that do not affect the variable capital. With the output variable namely profit after tax and results of data management using an dividends to the government with variables estimation analysis tool Banxia Frontier Analysis 3.0 shows that the three BUMD 
companies namely BPR BKK, PDAM Tirta effectiveness value of 1 or $100 \%$. Moedal, and Perusda RPH \& BPH have an

Picture 6. Level Efektivity BUMD in Semarang City Period 2016

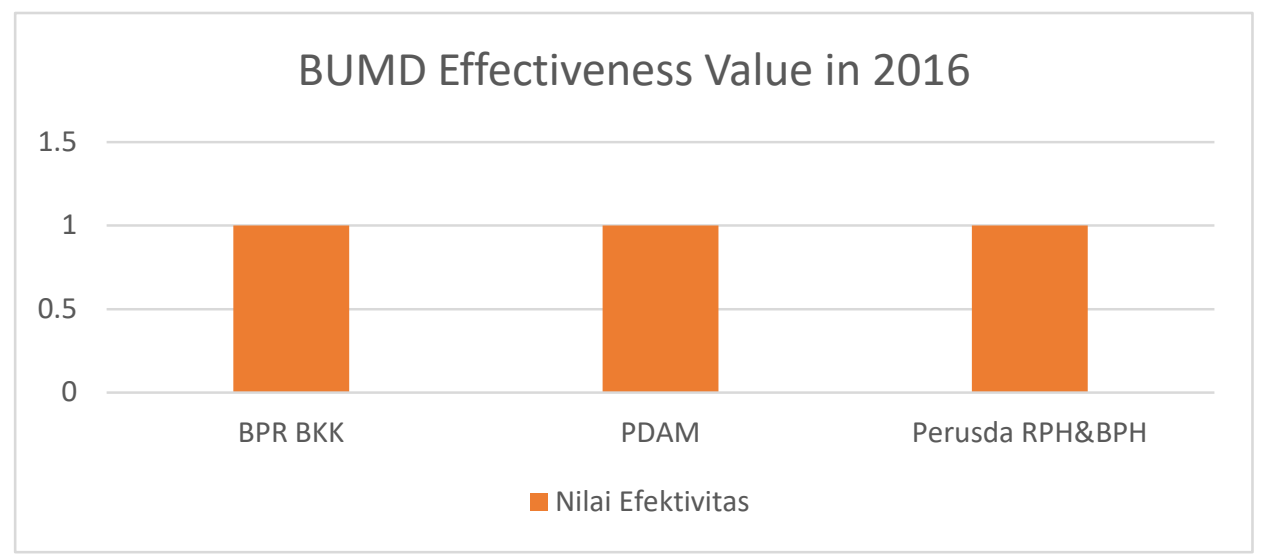

Sources: Data processed, 2018.

Level of Efficiency and Effectiveness of and Capital). With the results of Regionally Owned Enterprises (BUMD) in data management using an estimation analysis Semarang City Year 2014-2016

Measurement of the overall efficiency tool, Banxia Frontier Analysis 3.0 shows different results with annual efficiency level of BUMD in Semarang City in measurements. Following are the results 2014 - 2016 using variables ( Assets, Equity, of efficiency management in 2014- 2016. Profit After Tax, Dividends to Government,

Picture 7. Level of Efficiency and Inefficiency of the Semarang City BUMD period 2014-2016

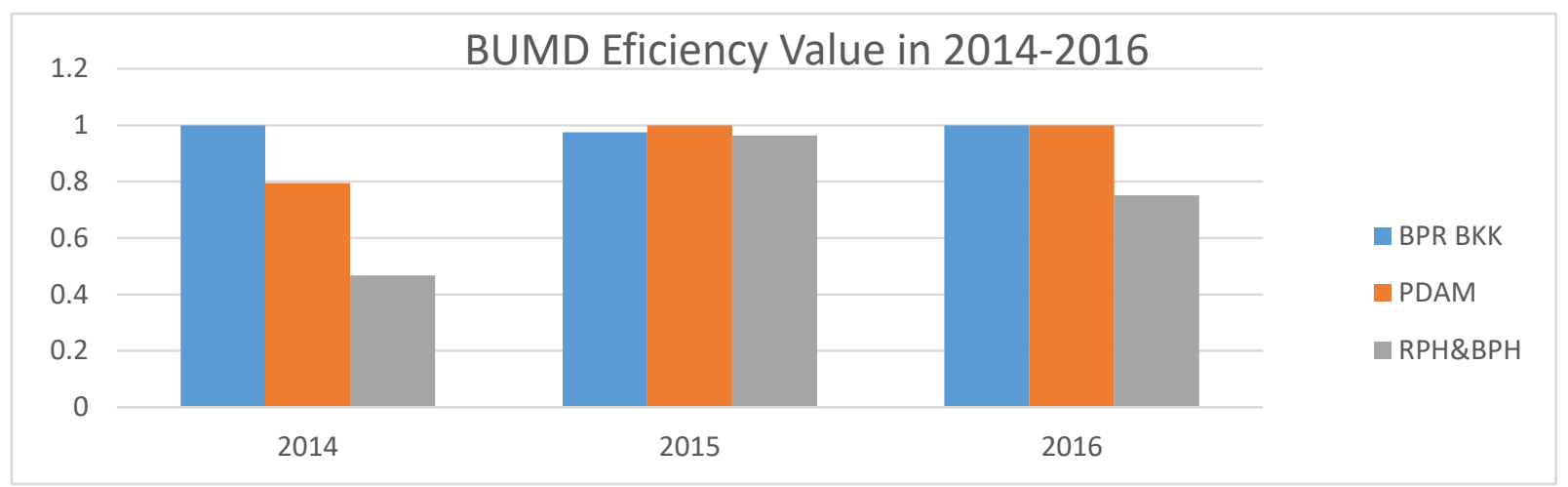

Sources: Data processed, 2018

In the graph above shows that in 2014 0.7942 or $79.42 \%$ and 0.4670 or $46.70 \%$. there were two companies that had an While BPR BKK has an efficiency value inefficiency value of less than 1 or $<100 \%$ of 1 or $100 \%$ in accordance with namely PDAM and RPH \& BPH with a value of the explanation 4.2.1 Efficiency Level in 2014. 
In 2015 showed that the BPR BKK experienced a decrease in the efficiency rate to 0.9741 or $97.41 \%$ indicating that in 2015 it did not reach the efficiency value. Then the RPH \& BPH Company experienced an increase in the efficiency value of 0.9629 or $96.29 \%$ but had not reached the efficiency value or $100 \%$. The PDAM company achieves an efficiency value of 1 or $100 \%$ in accordance with the explanation 4.2.4 Level of efficiency in 2015.

In 2016 shows that PDAM companies can maintain efficiency values of 1 or $100 \%$. Then for BPR BKK can increase the efficient value to 1 or become $100 \%$. However, on the RPH \&
$\mathrm{BPH}$ regulations, the decline was 0.751 or $75.1 \%$ indicating that the company had not achieved the efficiency value for the past 3 years. As for the measurement of the effectiveness of the Semarang City BUMD in 2014 - 2016 by using the output variable, namely profit after tax and dividends to the government with variables that do not affect the variable capital. With the results of data management using an estimation analysis by Banxia Frontier Analysis 3.0 shows different results with the measurement of effectiveness per year. The following are the results of various effectiveness management.

Picture 8. Level Efektivity BUMD in Semarang City Period $2014-2016$

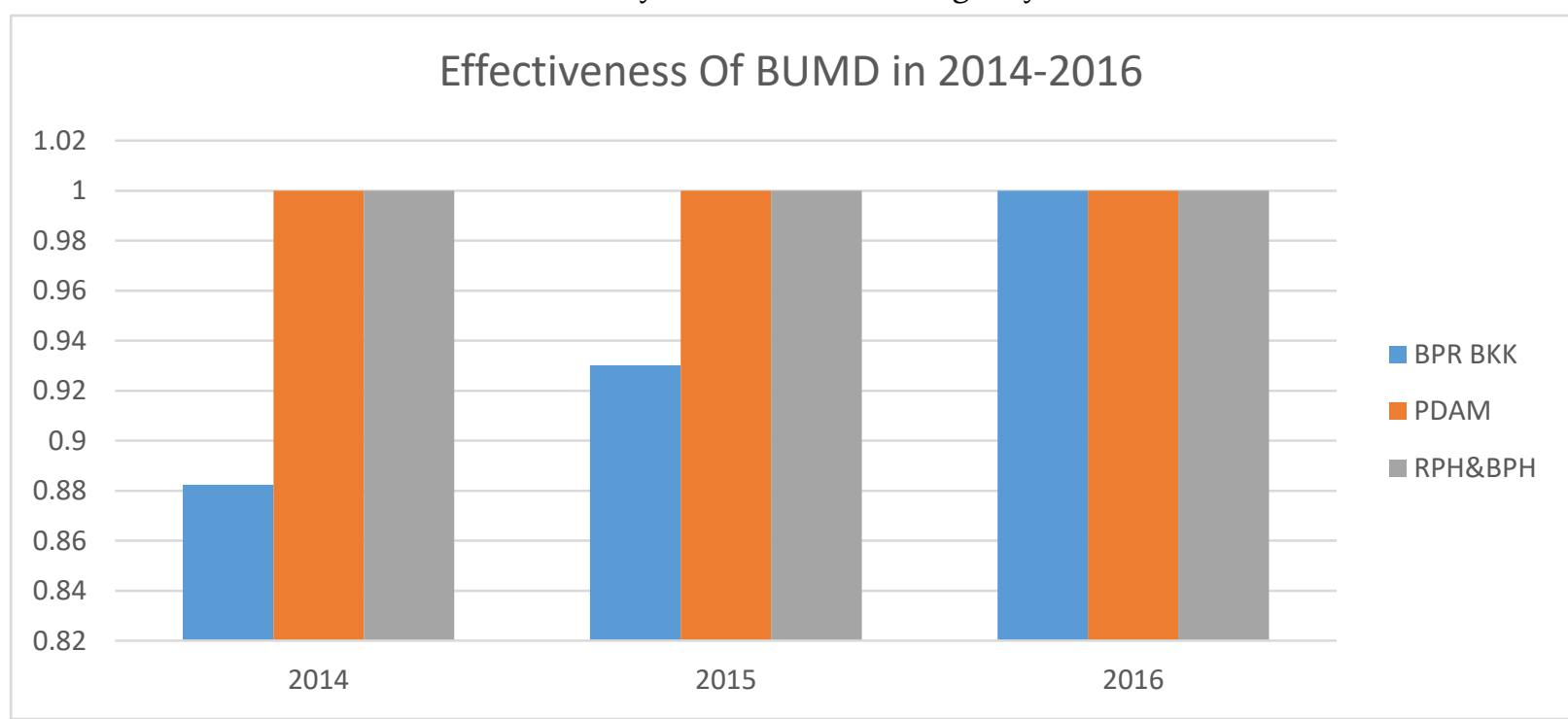

Sources: Data processed, 2018

In the graph above shows that in 2014 two companies namely PDAM and RPH \& BPH had a effectiveness level of $100 \%$. While for BPR BKK has not reached the effective level with a value of 0.8823 or $88.23 \%$ which means less than 1 or $<100 \%$.

In the graph above shows that in 2015 two companies namely PDAM and RPH \& BPH had a effectiveness level of $100 \%$. While for BPR BKK has increased by 0.9379 or $93.8 \%$ but has not reached the effective level which means less than 1 or $<100 \%$. In 2016 showed that all BUMD companies had reached the effectiveness level of 1 or $100 \%$.

\section{CONCLUSION}

Based on the results and discussion, the conclusions from this study are as follows;

Level of Efficiency in BUMD in Semarang City in 2014 there was only one company that 
had achieved efficiency value, namely BPR BKK company. Then in 2015 all BUMDs have achieved efficiency values, then in 2016 RPH \& $\mathrm{BPH}$ companies have not achieved efficiency value. The calculation together shows that the RPH \& BPH companies have not achieved the efficiency value from 2014 - 2016.

The level of effectiveness in BUMD in Semarang City by using annual calculations shows that the entire BUMD has achieved the value of effectiveness. However, the overall calculation shows that the BPB BKK has not been able to achieve the effectiveness value in 2014 and 2015 because of the need for additional dividends to the government in order to balance the value of post-tax profits.

The following suggestions are expected to help Regional Companies or BUMDs to improve Financial Performance and increase the Wealth Outcomes which are separated to assist the Government in increasing PAD (Regional Original Revenue).

To be able to improve the efficiency of the company, which is related to improving the financial performance of BUMDs by improving the company's assets such as buildings and machinery as an effort to increase service production so that it can deposit dividends to the Regional Government.

Increasing the value of effectiveness for BUMDs is done by increasing the company's profit after tax in order to maximize dividends to the government. BUMDs can collaborate with the government or private institutions to achieve synergy to create opportunities in increasing corporate revenues.

\section{BIBLIOGRAPHY}

Goncharuk, Anatoliy G.(2017). Efficiency VS Effectiveness: Alternative Metrics For Research Performance. Journal of Applied Management and Invesment, Vol.7 No.1, 24-37.

Kelbulan, Izak (2015) Analisis Pengaruh Penyertaan Modal Pemerintah Daerah Terhadap Pertumbuhan Aktiva, Efisiensi, Dan Kinerja Keuangan Bumd di Provinsi DIY. Skripsi. Yogyakarta: Universitas Atma Jaya Yogyakarta.

Peraturan Pemerintah Daerah Nomor 10 tahun 2014 Tentang Tambahan Penyertaan Modal Pemerintah Kota Semarang Kepada Badan Usaha Milik Daerah Kota Semarang Tahun 2014. Semarang : Pemerintah Daerah Kota Semarang.

Santosa, D. B. (2011). Kebijakan Optimalisasi Peran Badan Usaha MIlik Daerah (BUMD) Jawa Timur. Jurnal Aplikasi Manajemen, Vol 9 no 2.

Suseno, D. (2013). Efektivitas Dan Kemandirian Keuangan Daerah Provinsi Jawa Tengah Pasca Diterapkannya Desentralisasi Fiskal. Economics Development Analysis Journal, 2(2).

Undang-Undang Nomor 32 Tahun 2004 Tentang Pemerintah Daerah. Jakarta : Pemerintahan Negara Republik Indonesia.

Undang-Undang Nomor 33 Tahun 2004 Tentang Perimbangan Keuangan Antara Pemerintah Pusat dan Pemerintah Daerah. Jakarta : Pemerintahan Negara Republik Indonesia.

Umaruddin, U. (2012). Analisis Pengaruh Hasil Laba BUMD Tehadap Pendapatan Asli Daerah (PAD) Kabupaten Aceh Utara. Aceh: Universitas Malikussaleh. 


\section{APPENDIX}

Tabel 2. Realization of Results of Regional Property Management Semarang City period 2014 2016

\begin{tabular}{llllll}
\hline Company & $\begin{array}{l}\text { Realization } \\
2014(\mathrm{Rp})\end{array}$ & $\begin{array}{l}\text { Realization } \\
2015(\mathrm{Rp})\end{array}$ & $\begin{array}{l}\text { Estimation } \\
2016(\mathrm{Rp})\end{array}$ & Ratio (\%) & $\begin{array}{l}\text { Realization } \\
2016(\mathrm{Rp})\end{array}$ \\
\hline $\begin{array}{l}\text { 1.Perusda } \\
\text { RPH\& }\end{array}$ & - & 77.623 .330 & 150.000 .000 & 3.9 & 5.979 .510 \\
$\begin{array}{l}\text { BPH } \\
\text { 2.Perusda } \\
\text { Percetakan }\end{array}$ & 69.361 .514 & 120.038 .570 & 210.000 .000 & 80,68 & 169.439 .733 \\
$\begin{array}{l}\text { 3. Bank } \\
\text { Pasar }\end{array}$ & 91.006 .744 & 249.489 .648 & 368.280 .000 & 101,3 & 373.120 .164 \\
$\begin{array}{l}\text { 4. Bank } \\
\text { Jateng }\end{array}$ & 9.334 .601 .607 & 11.890 .281 .241 & 50.000 .000 .000 & 23,78 & 17.302 .745 .502 \\
$\begin{array}{l}\text { 5.BPR/BKK } \\
\text { Total }\end{array}$ & 1.035 .606 .835 & 1.071 .546 .959 & 1.251 .353 .000 & 85,63 & 1.180 .070721 \\
\hline
\end{tabular}

Sources : Notes of Financial Statements in Semarang city period 2016 